\title{
Production and Acceptability of Jam Produced from Pineapple, Watermelon and Apple Blends
}

Nafisah Salam $^{1 *}$, Konadu Lydia ${ }^{2}$, Kafui Senya Elizabeth ${ }^{3}$

${ }^{1}$ Assistant Lecturer-Hospitality and Tourism Department, University of education, Winneba-kumasi campus, Ghana

${ }^{2}$ S D A College of Education, Box 29, Agona Ashanti,-Ghana

${ }^{3}$ Department of Hotel, Catering and Institutional Management, Accra Technical University, Accra-Ghana

\section{Article History}

Received: 07.12.2020

Accepted: 18.12 .2020

Published: 23.12.2020

Journal homepage:

https://www.easpublisher.com

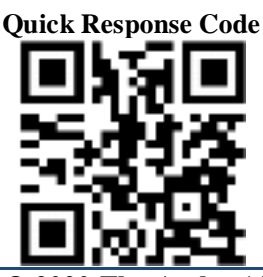

Abstract: The aim of the study was to prepare an acceptable jam from pineapple, apple and watermelon blends. The proximate composition of the jam samples was determined. Jams were produced from a blend of pineapple, apple and watermelon in the ratio 100:0:0, 70:20:10 and 60:20:20 respectively. The proximate composition result of the jam produced indicated moisture content between $40.32-65.21 \%$, ash content of $0.30-0.63 \%$, fat content of $0.02-0.18 \%$, protein content of $0.23-0.99 \%$ and carbohydrate content of $33.00-58.96 \%$. The sensory properties of the jam sample B showed significant $(p \leq 0.05)$ different in colour, aroma, taste and overall acceptability of the jam. Sample B (70\% pineapple, $20 \%$ apple and $10 \%$ watermelon) was preferred in terms of colour, aroma appearance taste and texture. The findings reveal that pineapple, apple and watermelon could be used in the preparation of a quality jam without any adverse effect on the nutritional quality.

Keywords: Pineapple, watermelon, apple, jam, composite ingredients, proximate composition.

Copyright (C) 2020 The Author(s): This is an open-access article distributed under the terms of the Creative Commons Attribution 4.0 International License (CC BY-NC 4.0) which permits unrestricted use, distribution, and reproduction in any medium for non-commercial use provided the original author and source are credited.

\section{INTRODUCTION}

Jam is characterized as a sweet spread made after boiling grated or chopped fruits pulp with adequate amount of sugar, gelatin, citric acid, and other ingredients, for example, preservatives, and flavouring agent to a gel like consistency which is sufficiently firm to hold the fruit tissues in position [1]. Jams contain about $68.5 \%$ complete soluble substances and $45 \%$ of the fruits pulp [2], uncovered that jam ought to contain over $65 \%$ all out dissolvable solids in finished product [3]. Jam and jelly is one basic natural product prepared from fruits [4].

Apple (MalusSylvestris) belongs to rosaceae family and sub-family pomoidae. Apple contains $84.7 \%$ water, $13.9 \mathrm{~g}$ carbohydrates, $0.3 \mathrm{~g}$ lipids, $0.4 \mathrm{~g}$ protein and vitamin C $8 \mathrm{mg}$ per 100 from of consumable fruit. Apples are rich wellspring of cell reinforcements including flavonoids and polyphenols mostly happens in its skin. In this way, eating entire apple is recommended to obtain full health benefits [5].

Apple has high nutritional benefits and it is a decent source of vitamin $\mathrm{C}$, Potassium and fiber. It contains $11 \%$ sugar, $0.3 \%$ proteins, $14 \%$ starches, $4 \%$ nutrients and minerals and remaining piece of apple contains water [3]. Apple has a great mending power for maintaining wellbeing and helps to relief the body from numerous infections such as diabetes, cardiovascular sicknesses, joint inflammation, blockage, disease, ailment, looseness of the bowels, Alzheimer and furthermore lessens chances for gallstones arrangement [6-9].

Watermelon belongs to the family known as cucurbitaceae, and it is a warm-season crop identified with squash, cucumber and pumpkin [10]. The entire watermelon is consumable, including the skin. It is low in calories however profoundly nutritious; it contains Vitamin $\mathrm{C}$ and Vitamin $\mathrm{A}$ in form of the disease battling beta-carotene. Potassium is likewise accessible in the watermelon which helps in the control of blood pressure and perhaps forestalls strokes [11].

Pineapple (Ananas comosus), is a tropical fruit which could be eaten raw, juice or stewed [12]. The pulp is yellow to intense yellow, sweet, and succulent, pineapple might be made into confections, and consolidated into cooked dishes and pastries. The fruit is a decent wellspring of dietary fiber, stacked with nutrients and minerals, and particularly plentiful in vitamin $\mathrm{C}$ and manganese [12]. The purpose this 
research work was to produce an acceptable jam from pineapple, apple and watermelon.

\section{Materials ANd Methods}

Source of raw material

The pineapple, pawpaw and apple were obtained from Kumasi central Market, the Ashanti Region of Ghana. Other materials such as ginger, sugar, and lemon were obtained from Tafo Market.

\section{Sample preparation}

Samples of pineapple, watermelon and apple were sorted, washed with potable water to remove adhering soil, and peeled manually with stainless steel knife. The peeled fruits were washed with portable water and sliced into $2 \mathrm{~mm}$ thickness with a manual stainless steel knife, and the peeled sample were milled using an electric hand mill and sieved using conical mesh. The various sample obtained from the pineapple, watermelon and apple was packaged separately, sealed and stored at $5{ }^{\circ} \mathrm{C}$.

\section{Sample formulation}

Three different jam samples were produced and coded as A, B, and C. Sample A served as control and contained $100 \%$ pineapple. Samples B 70\% pineapple, $20 \%$ watermelon and $10 \%$ apple, and sample C $60 \%$ pineapple, $20 \%$ watermelon and $10 \%$ apple.

Table-1: Formulation of ingredients for Jam Preparation

\begin{tabular}{|r|r|r|r|}
\hline INGREDIENTS & SAMPLE A & SAMPLE B & SAMPLE C \\
\hline Pineapple & $100 \mathrm{~g}$ & $70 \mathrm{~g}$ & $60 \mathrm{~g}$ \\
\hline watermelon & - & $20 \mathrm{~g}$ & $20 \mathrm{~g}$ \\
\hline Apple & - & $10 \mathrm{~g}$ & $20 \mathrm{~g}$ \\
\hline Sugar & $100 \mathrm{~g}$ & $100 \mathrm{~g}$ & $100 \mathrm{~g}$ \\
\hline Lemon $(\mathrm{ml})$ & 10 & 10 & 10 \\
\hline Water $(\mathrm{ml})$ & 500 & 500 & 500 \\
\hline Ginger & $5 \mathrm{~g}$ & $5 \mathrm{~g}$ & $5 \mathrm{~g}$ \\
\hline
\end{tabular}

Sample A 100\% Pineapple, sample B = 70\% pineapple, 20\% watermelon and 10\% apple, Sample C $=60 \%$ Pineapple, $20 \%$ watermelon and $20 \%$ apple

\section{Preparation of the jam}

An acceptable jam was prepared using the method described by [13] with minor modifications. The fruits were washed twice with potable water and wiped with a clean dish cloth. Fruits were then cut and peeled manually with while wearing non-medicated gloves. The seeds were removed manually. The pulps $(400 \mathrm{~g})$ were blended separately for 4 minutes using an electric blender (Panasonic MX-GX 1021). Sugar $(400 \mathrm{~g})$ lime juice $(10 \mathrm{ml})$ were added to each of the pulp. The mixture was left at room temperature for 20minutes and subsequently cooked slowly with infrequent stirring for 15 minutes. The jam was poured into a sterilized bottle and allowed to cool at a room temperature (290 C-320 C) for further analysis.

\section{Proximate Analysis}

Proximate composition analysis of the jam was carried out at The experiment was conducted at the Mycotoxin and Food Analysis laboratories, Department of Food Science and Technology, College of Science,
Kwame Nkrumah University of Science and Technology, Kumasi, Ghana. The overall content of moisture, ash, fat, protein, and carbohydrate of jam sample was determined [14].

\section{Sensory Analysis}

The jam samples were served along with a sliced of tea bread and was presented to 50 untrained consumers to indicate their observations and rate the samples parameters; colour, texture, aroma, taste, aftertaste, appearance and overall acceptability. The analysis was carried out on the three (3) samples.

\section{Statistical Analysis}

All analytical determinations were conducted in duplicates. Means and standard deviations were calculated. Data obtained was subjected to analysis of variance (ANOVA) where significant differences exist; Tukey's test was used in separating the means.

\section{Results AND DisCuSSION}

Table-2: the sensory analysis of the jam

\begin{tabular}{|l|l|l|l|l|l|}
\hline Samples & Colour & Texture & Aroma & Taste & Level of acceptability \\
\hline A & $4.40 \pm 0.7$ & $4.10 \pm 0.80$ & $4.3 \pm 0.80$ & $4.40 \pm 0.80$ & $4.50 \pm 0.70$ \\
\hline B & $4.80 \pm 0.44$ & $4.20 \pm 0.60$ & $4.70 \pm 0.54$ & $4.6 \pm 0.60$ & $4.60 \pm 0.53$ \\
\hline C & $4.50 \pm 0.70$ & $4.00 \pm 09$ & $4.20 \pm 0.80$ & $4.50 \pm 0.70$ & $4.50 \pm 0.60$ \\
\hline LSD & 0.42 & 0.24 & 0.56 & 1.462 & 0.04 \\
\hline
\end{tabular}

(Source: field survey, 2020)

Sample A (100\% pineapple) Sample B (70\% pineapple, $20 \%$ apple and 10\% watermelon) Sample C (60\% pineapple, $20 \%$ apple and $20 \%$ watermelon) 


\section{Colour}

The colour of the composite sample B $(70 \%$ pineapple, $20 \%$ apple and $10 \%$ watermelon) was significantly $(\mathrm{p}<0.05)$ different from the control samples A $(100 \%$ pineapple) with the highest mean score of approximately 4.80 , that is "liked very much". The control sample had the lowest mean score of 4.40 . The likeness of the colour of composite jam may be as a result of the combination of low quantity of watermelon and apple into the jam.

\section{Texture}

It was observed that the texture of the composite sample $\mathrm{B}$, had the highest mean score of approximately 4.2 as compared to the control sample 4.10. There were no significant $(p<0.05)$ different between the control and the composite sample B. The present findings are in agreement with observed values of [15], who observed a gradual decline in the texture properties of strawberry jam. The present value for texture are found to be slightly lower than the findings of [16], who observed a decrease in the value of texture of grape and apple marmalade during storage. Similarly, [17], analyzed decrease in texture score from 9.00 to 6.70 in apple jam. Texture comprises those properties of product which is judged visually or by touch.

\section{Aroma}

The aroma of any product normally influence its acceptability. The composite sample (B) had the high mean score of approximately 4.70 whilst the control sample recorded 4.30. The observation indicates a significant difference between the aroma of the control and that of sample B.

Taste

The composite sample B, had the highest mean score of approximately 4.6 against the control with 4.40 least mean score. However, there were significant $(\mathrm{p}<0.05)$ different between the control sample and the composite sample B. Conversely, the study is in line with [18] as well as [19] whose work revealed that the taste of jam processed from blends of pineapple, tomato and pawpaw showed superiority over the control (commercial strawberry jam). They recorded (7.85 point) of taste compared slightly low to jam from apple (8.3 point) and coconut based jam (9.0 point) [20] further recorded a high mean score for taste of the composite jam produced.

\section{Overall acceptability}

The quality of the jam (Aroma, colour, texture, appearance and taste) had indeed influenced the overall acceptability of the jam. There was no significant $(\mathrm{p} \leq 0.05)$ difference between the control and the composite samples (B and $\mathrm{C}$ ) in the overall acceptability. The composite sample $\mathrm{B}$, had the highest mean score of 4.6 with the control sample recording the mean score of 4.5. The study therefore disagrees with the findings of [16] who recorded a decreased in the overall acceptance of grape and apple marmalade from 8.8 to 7.96 during the storage interval. Similarly, [21] also examined similar results of decreasing trends $(9.00$ to 7.00) in overall acceptability in fruit jam. Moreover, [22] established decline in the overall acceptability of lemon and watermelon jam.

Table-3: proximate composition of pineapple, watermelon and apple jams

\begin{tabular}{|l|l|r|c|c|l|}
\hline Samples & Moisture \% & Ash\% & Fat\% & Protein\% & Carbohydrate\% \\
\hline A & $40.32 \pm 0.95$ & $0.30 \pm 0.07$ & $0.18 \pm 0.01$ & $0.23 \pm 0.11$ & $58.96 \pm 0.92$ \\
\hline B & $63.46 \pm 0.71$ & $0.63 \pm 0.01$ & $0.07 \pm 0.01$ & $0.97 \pm 0.34$ & $34.87 \pm 0.40$ \\
\hline C & $65.21 \pm 0.20$ & $0.60 \pm 0.04$ & $0.02 \pm 0.01$ & $0.99 \pm 0.64$ & $33.00 \pm 0.88$ \\
\hline
\end{tabular}

(Source: Lab. Test, 2020)

Sample A (100\% pineapple) Sample B (70\% pineapple, 20\% apple and 10\% watermelon) Sample C (60\% pineapple, $20 \%$ apple and $20 \%$ watermelon)

The result of the proximate analysis of the composite jam is presented in Table 3. The moisture content ranged from 40.32 to $65.21 \%$. The control sample has lowest moisture content of $40.32 \%$ different from the composite jams. However, the moisture content may also be as a result of boiling temperature and the variation of ingredients used. Sample $\mathrm{C}$ had highest moisture content which may be as a result of combination of the fruits (pineapple, watermelon and apple in high proportion) or the presence of the watermelon may have caused that. The moisture high content can cause microbial infection in the jam. The results were not in line with [21] who studied grape fruit apple marmalade and reported decreasing trend in $\%$ moisture [23], observed decreased in \% moisture from $79 \%$ to $77 \%$ after 60 days of storage in dried apricot jam.

The ash content of the pineapple jam is $0.30 \%$, which is lower compared to $0.60 \%$ of the composite blends of 70:20:10 fruits. The sample (B) had the highest ash level of $0.63 \%$ when compared to other samples. The ash content of the composite jam samples were higher compared to the data obtained for prickly pear jam [24]. Ash content gives an indication of minerals composition of food sample is very important in many biochemical reactions which aid physiological functioning of major metabolic processes in the body [25]. This might be attributed to the ratio of composition of the fruit pulps. There was a significance $(\mathrm{p} \leq 0.05)$ difference between the control sample A 
(100\% pineapple) and the jam blends B (70\% pineapple, $20 \%$ apple and $10 \%$ watermelon) Sample C (60\% pineapple, $20 \%$ apple and $20 \%$ watermelon).

The control sample A (100\% pineapple) had the highest fat content of $0.18 \%$ followed by sample B (70\% pineapple, $20 \%$ apple and $10 \%$ watermelon) with $0.07 \%$ and sample (C) with $0.02 \%$. This observation can be concluded that, the increase in percentage of fruits may cause the fall in the fat level of jams in sample $\mathrm{B}$ and $\mathrm{C}$ respectively.

The protein content of the pineapple jam ranged from $0.23 \%$ to $0.99 \%$. Sample B, made up of (70\% pineapple, $20 \%$ apple and $10 \%$ watermelon) recorded high protein content of $0.99 \%$. The protein content increased with increase in the substitution level of the fruits in sample (B and C).

\section{CONCLUSION}

The study revealed that acceptable jams could be produced from pineapple, watermelon and apple in the ratio 70:20:10 without adverse effects on the nutritional value. This will help in reducing wastage of these fruits but also boost its productions, utilization as well as the income of farmers and reduce the pressure on the use of other fruits for jam production.

\section{REFERENCES}

1. Hussain, T. (2001). Food composition table for Pakistan. Govt. of Pak., Ministry of P \& D Islamabad,

2. Codex, A. C. 2009). Codex Standard for Jams, Jellies and Marmalades'. Codex Stan 296, Codex Alimentarius Commission, Rome, Italy.

3. Baker, R.A., Berry, N., Hui, H.Y., \& Barret D.M. (2001). Food preserves and jams'. Second ed. CRC press, Boca Raton, FL, USA: 02-03,

4. Manay S.N., \& Shadaksharaswamy, N. (2005). Foods, Facts and principles" New Age International (P) Limited, New Delhi, 197,

5. Khan, S.H, Shah, A.S., Bilal, M., Khan A., Ali, M.U., Rani, S. (2015). Comparative studies on the shelf stability of different types of apple jams. Pak J Food Sci, 25: 37-42.

6. Khair, M.S., Shahwani, N.M., Shah, S.A. (2013). Production of Constraints of Apple retrieved from on August 28, www.scribd.com/doc/52635102/List-PHD-ThesisJan 2011

7. Gerhauser, C. (2008). Cancer chemo-preventive potential of apples, apple juice, and apple components'. Planta Medica; 74: 1608-24.

8. Kunkel, S. D., Elmore, C. J., Bongers, K. S., Ebert, S. M., Fox, D. K., Dyle, M. C., ... \& Adams, C. M. (2012). Ursolic acid increases skeletal muscle and brown fat and decreases diet-induced obesity, glucose intolerance and fatty liver disease. PloS one, 7(6), e39332.
This result indicated that the blend samples had high protein content which was similar to the protein content of prickly pear pulp (7.02 - 8.51\%) [24]. There was a significant $(\mathrm{p} \leq 0.05)$ difference between the control sample A (100\% pineapple) and the composite jam samples B (70\% pineapple, $20 \%$ apple and $10 \%$ watermelon) with $0.07 \%$ and sample (C) with $0.02 \%$.

The carbohydrate content of the control (A) is $58.96 \%$. However, the carbohydrate content of the composite jams ranged from $34.87 \%-33.00 \%$ for sample $\mathrm{B}$ and $\mathrm{C}$ respectively. The highest carbohydrate content observed in sample ' $A$ ' might be attributed to the high carbohydrate content in pineapple [26]. A significance $(p \leq 0.05)$ difference was observed in the control and the composite samples; A (100\% pineapple) Sample B (70\% pineapple, $20 \%$ apple and $10 \%$ watermelon) Sample C (60\% pineapple, $20 \%$ apple and $20 \%$ watermelon)

9. Guhr, G., \& Lachance, P. A. (1997). Role of phytochemicals in chronic disease prevention. Nutraceuticals: Designer foods III garlic, soy, and licorice, 311-64.

10. George-Boyhan, E., Darbie-Granberry, M., \& Terry-Kelley, W. (2000). Commercial Watermelon Production'. The University of Georgia. College of Agricultural and Environmental Sciences and the U. S. Department of Agriculture cooperating, 1-32.

11. Adekunle, A. A., Fatunbi, A. O., Adisa, S., \& Adeyemi, O. A. (2007). Growing watermelon commercially in Nigeria: An illustrated guide. USAID ICS-NIGERIA and IITA. Retrieved October, 5, 2012.

12. Ackom, N. B., \& Tano-Debrah, K. (2012). Processing pineapple pulp into dietary fibre supplement. African Journal of Food, Agriculture, Nutrition and Development, 12(6).

13. Adepoju, O. T., Adigun, M. O., Lawal, I. M., \& Olaide, E. A. (2010). Nutrient and Anti nutrient Composition of Jams Prepared from Hibiscus sabdariffa Calyx Extract. Nigerian Journal of Nutritional Sciences, 31(1), 8-11.

14. Pathak, P. K., \& Ivi, C. (2006). Studies on physicochemical characters of some potential underutilized tropical fruits. In Proceedings of the national symposium on production, utilization and export of underutilized fruits with commercial potentialities, Kalyani, Nadia, West Bengal, India, 22-24 November, 2006 (pp. 271-274). Bidhan Chandra Krishi Viswavidyalaya.

15. Suutarinen, J., Honkapää, K., Heiniö, R. L., Autio, K., \& Mokkila, M. (2000). The effect of different prefreezing treatments on the structure of strawberries before and after jam making. $L W T$ Food Science and Technology, 33(3), 188-201.

16. Bajwa, E. E., Parwaz, N. Z., Ghafoor, A., \& ResearchInst, A. A. (2002). Development, standardization and storage studies on watermelonlemon jam. Pakistan Journal of Food Sciences (Pakistan). 
17. Rathore, H. A., Masud, T., Sammi, S., \& Soomro, A. H. (2007). Effect of storage on physicochemical composition and sensory properties of mango (Mangifera indica L.) variety Dosehari. Pakistan Journal of Nutrition, 6(2), 143148.

18. Muhammad, A., Durrani, Y., Ayub, M., Zeb, A., \& Ullah, J. (2009). Organoleptic evaluation of diet apple jam from apple grown in Swat valley. Sarhad Journal of Agriculture, 25(1), 81-86.

19. Sindumathi, G., \& Amutha, S. (2014). Processing and quality evaluation of coconut based jam. IOSR J. Environ. Sci. Toxicol. Food Technol, 8(1), 10-14.

20. Levaj, B., Dragović-Uzelac, V., Dančević, T., Liber, S., Repajić, M., \& Bursać Kovačević, D. (2009). Quality of clementine jam influenced by purée pretreatment, sugar type and pectin addition. Agriculturae Conspectus Scientificus, 74(3), 227-231.

21. Bajwa, E. E., Parwaz, N. Z., Javed, A., \& Ahmad, N. (2003). Development, standardization and storage studies on grape fruit apple marmalade. Pak. J. Ford Sci, 13(3-4).

22. Imtiaz, H., \& Iftikhar, S. (2010). Chemical and organoleptic characteristics of jam prepared from indigenous varieties of apricot and apple. World Journal of Dairy \& Food Sciences, 5(1), 73-78.

23. Anjum, F. M., Din, M. U., Ahmad, I., \& Pasha, A. R. (2000). Preparation and evaluation of dried apricot diet jam. Pak. J. Food Sci, 3(10), 21-24.

24. Atef, A. M., Abou-Zaid, N., Ibrahim, I., Ramadan, M. T., \& Nadir, A. (2013). Quality evaluation of sheets, jam and juice from prickly pear and melon blends. Life Sci. J, 10, 200-208.

25. Ashaye, O. A., \& Adeleke, T. O. (2009). Quality attributes of stored Roselle jam. International Food Research Journal, 16(3), 363-371.

26. Augstburger, F., Berger, J., Censkowsky, U., Heid, P., Milz, J., \& Streit, C. (2000). Organic farming in the tropics and subtropics. Exemplary description of, 20 . 